\title{
Propaganda E ResistênCia no Egito Romano: \\ a Estela de Cornélio Galo
}

\author{
Marcia Severina Vasques ${ }^{1}$
}

\section{RESUMO}

O Egito romano era uma sociedade múltipla e heterogênea, que pode ser analisada tanto do ponto de vista de elementos de continuidade com uma tradição que remonta ao período faraônico quanto com transformações decorrentes das séries de conquistas estrangeiras que o país sofreu. Refletindo sobre a ideologia real no Egito Romano, temos por objetivo abordá-la considerando dois enfoques diversos: seu valor enquanto elemento de propaganda política pelos governantes romanos e o seu uso como forma de resistência egípcia ao domínio estrangeiro. Um elemento essencial à nossa interpretação é a estela de Cornélio Galo, primeiro prefeito de Alexandria e do Egito.

PALAVRAS-CHAVE

Egito Romano; ideologia real; propaganda; resistência; Cornélio Galo.

\footnotetext{
${ }^{1}$ Professora do Departamento de História do Centro de Ciências Humanas, Letras e Artes (CCHLA) da Universidade Federal do Rio Grande do Norte (UFRN). E-mail de contato: vasquesms@gmail.com
} 
Mare Nostrum, ano 2020, v. 11, n. 2.

\section{Introdução}

Cornélio Galo foi o primeiro prefeito de Alexandria e do Egito, em 30-29 a.C. (Milne, 1992, pp. 1-6), quando o Egito se tornou uma província romana. Otávio derrotou Cleópatra VII e Marco Antônio na Batalha de Ácio, pondo fim a aproximadamente trezentos anos de domínio greco-macedônico ${ }^{2}$. Após a ocupação romana, o Egito tornouse uma província imperial e passou a ser administrado por um praefectus, uma espécie de governador pertencente à ordem equestre. Otávio, que recebeu o título de Augusto ${ }^{3}$ em 27 a.C., recém-saído de um período de instabilidade gerado pela guerra, preocupava-se com o possível uso político do país. Por isso, proibiu os senadores de entrarem no Egito sem a sua prévia autorização e escolheu um prefeito da ordem equestre.

Muito se tem debatido sobre o motivo da queda de Cornélio Galo, seu suicídio, em 26 a.C., e consequente damnatio memoriae (Grenier, 1997; Minas-Nerpel \& Pfeiffer, 2010; Solieman, 2014). Não é nossa pretensão chegar a uma conclusão a respeito, mas sim discorrer sobre um aspecto que consideramos relevante no caso em questão: o uso político da sua vitória sobre a Revolta da Tebaida, que aconteceu no Alto Egito no início do domínio romano, relatada por Estrabão (Geographia, XVII, 1.53), contemporâneo do episódio. Cornélio Galo mandou erigir uma estela comemorativa no pátio do templo de Ísis, na ilha de Philae. A estela, atualmente quebrada em duas partes e muito deteriorada, faz parte do acervo do Museu do Cairo (CG9295). Foi escrita em três línguas, a egípcia (no formato de hieróglifos), o grego e o latim, e possui elementos relacionados à tradição egípcia, já adaptada pelos macedônios, com imagem esculpida em relevo e texto.

A estela será por nós utilizada para refletir sobre o uso da ideologia real como forma tanto de propaganda quanto de resistência. Propaganda feita pelos romanos, no caso específico o próprio Cornélio Galo em nome de Augusto, temática controversa ainda em debate. O outro aspecto da ideologia real que abordaremos é o seu uso enquanto forma de resistência dos egípcios, não apenas aos romanos, mas aos estrangeiros de uma forma geral. Dividimos o artigo em três tópicos: o primeiro abordando o conceito de ideologia

\footnotetext{
${ }^{2}$ A conquista do Egito, então sob domínio persa, por Alexandre, o Grande ocorreu em 332 a.C. Durante o reinado de Alexandre o Egito foi administrado por um sátrapa chamado Cleômenes de Náucratis. Após a morte do rei, Ptolomeu, que tinha sido general de Alexandre, foi sátrapa do Egito sob os governos dos sucessores de Alexandre: primeiro o seu meio-irmão, Filipe III Arrideu e, depois, seu filho, Alexandre IV. Após a derrota de Pérdicas, o regente da Macedônia, que tentou invadir o Egito em 321 a.C., o poder de Ptolomeu aumentou consideravelmente até ele ser coroado oficialmente faraó em 305 a.C. (Bowman, 1986, p. 22).

${ }^{3}$ A fim de evitar duplicidade no texto, daqui em diante passo a designar Otávio como Augusto, mesmo antes de ele ter recebido o título honorífico.
} 
real e propaganda para o Egito Antigo e seus conquistadores romanos; a estela de Cornélio Galo; e, por último, a sua Damnatio memoriae.

\section{Ideologia real}

É sempre problemático o uso de conceitos modernos aplicados ao mundo antigo e, em especial, ao Egito. Donald Redford (2008, p. 32), considera negativo o uso do termo propaganda real, pelo seu sentido de necessidade de convencimento do público, pois não havia liberdade de escolha no Egito, já que a concepção de mundo estava pautada pela ideia de Maat, a ordem cósmica e social. Quando a crítica ao sistema aparecia, era dentro dessa visão.

Ao invés de recorrer ao termo propaganda, Redford (2008, p. 32) prefere analisar o discurso real, quando trata das fontes escritas de caráter oficial. No nosso caso, optamos pelo termo ideologia real, defendido por Barry Kemp (2018), quando aborda os fundamentos do Estado egípcio. Para Kemp (2018, pp. 57-58), a ideologia é essencial a todo Estado, antigo ou moderno, possuindo uma imagem idealizada, que forma uma identidade única. O governante tem o poder de sanção, que utiliza para mobilizar os recursos e a energia da população, por meio das instituições e de um sistema burocrático.

A coesão do Estado egípcio se dava pela ideia de ordem (Maat), que deveria ser mantida pelo faraó, ao controlar as forças do caos. Era função do faraó afastar tudo que fosse considerado negativo, mantendo a prosperidade e unidade do país contra a anarquia. Segundo Jan Assmann, na concepção egípcia de mundo, o Estado existia exatamente para a manutenção de Maat, pois "Maat deve ser realizada para que o mundo seja habitável" (Assmann, 2010, p. 113). Para tanto, o rei deveria fazer justiça e agradar aos deuses e aos mortos imortalizados, por meio das oferendas depositadas nos templos e nas tumbas (Assmann, 2010, p. 116-117). Maat, como princípio fundador do Estado egípcio, vinha desde a criação do mundo pelo demiurgo, o deus-sol. A manutenção da ordem e o afastamento de isfet, o seu oposto, deveriam ser obra do faraó, cujo cargo derivava do próprio Rê (Assmann, 2010, p. 115).

Os estrangeiros, em contextos oficiais de representação, aparecem de forma negativa como pertencentes à força destruidora de isfet. $\mathrm{O}$ arco, símbolo guerreiro por excelência, era associado aos não-egípcios, que na época faraônica eram repartidos em três tipos gerais: os asiáticos, os núbios e os líbios (Valbelle, 1990, p. 46). O termo "Nove Arcos" para designar os inimigos do Egito já estava presente no Reino Antigo (c. 2575- 
Mare Nostrum, ano 2020, v. 11, n. 2.

2134 a.C.) ${ }^{4}$ e, talvez, seja anterior, remontando ao início do período dinástico (c. 2920 a.C.). O número nove indicava, como múltiplo de três, a totalidade dos inimigos do Egito (Wilkinson, 1994, p. 137).

Mesmo os estrangeiros que dominaram o Egito sentiram necessidade de sustentar o seu governo com base nos parâmetros egípcios da realeza divina, pois essa era a forma de manutenção do controle do território e de sua população. No Egito, as tradições faraônicas se perpetuaram até o século IV d.C., com os imperadores romanos sendo retratados nos relevos dos templos como faraós, assim como tinham sido antes deles os Ptolomeus, os persas e os núbios. Podemos nos perguntar se, no caso dos romanos, o termo propaganda seria adequado para essas representações nos templos egípcios. Paul Zanker, quando analisa as imagens romanas produzidas de Augusto, avalia que não havia em Roma uma "máquina de propaganda" propriamente dita e sim um processo espontâneo de homenagens de longa duração (1990, p. 3). Já nas províncias orientais a figura do imperador poderia se associar a antigos mitos e cultos de heróis (1990, p. 300). Para Dundas (2002, p. 435), a religião imperial tinha um aspecto político, com a finalidade de integrar a figura do imperador à mentalidade local das províncias.

No Egito, a representação do imperador romano como faraó não deveria gerar estranheza, pois outros estrangeiros já tinham assim sido representados e era uma forma de manter a coesão social e a estabilidade política no país. No entanto, ao que parece, esta transposição - dos imperadores romanos como faraós - não foi uma solução tão simples e fácil, pelo menos no início da administração romana do Egito. Suetônio e Dião Cássio narram duas anedotas em relação ao comportamento de Augusto quando de sua estadia no Egito. Em Alexandria, Augusto prestou homenagens ao corpo de Alexandre, o Grande, sobre a cabeça do qual depositou uma coroa de ouro, mas se recusou a visitar as tumbas dos Lágidas (Suetônio, Divus Augustus, 18). E, quando foi a Mênfis, não quis visitar o touro Ápis no Serapeum afirmando que não se prostrava diante de bois, apenas de deuses (Suet, Aug. 93; Dião Cássio, Historiae Romanae, LI.16.5).

Como troféu de sua conquista do Egito, Augusto mandou transportar para Roma dois obeliscos do templo de Heliópolis. Segundo Grenier (1997, p. 38), foram três os atos de Augusto que poderiam ser considerados como "sacrilégios" na visão egípcia: a falta de respeito aos "reis ancestrais"; o desprezo por um rito essencial à monarquia egípcia, na ligação entre o faraó e o touro Ápis, cujo santuário era de suma importância para os

\footnotetext{
${ }^{4}$ Utilizamos a cronologia egípcia estabelecida por Baines e Málek (1996, pp. 36-37).
} 
egípcios; e o butim de guerra levado do templo de Heliópolis, um dos mais tradicionais do Egito, cujas origens remontavam ao Reino Antigo, quando o faraó já recebia o título de "filho de Rê". Esta atitude de Augusto, embora mais moderada, lembra a de Cambises, relatada por Heródoto (Historiae, III.29), que, provavelmente em um exagero retórico, aparece como tendo posto fogo na múmia de Amásis ${ }^{5}$, de ter apunhalado o touro Ápis e de ter incendiado o templo de Heliópolis. A história de Cambises parece ser, de certa forma, um modelo do mau governante. Mas embora Suetônio e Dião Cássio possam ter sido influenciados pela narrativa de Heródoto, ambos não viram a atitude de Augusto como negativa. Pelo contrário, ela assinalava a sua romanidade (Orlin, 2008, pp. 233234).

Ao contrário de Grenier (1997, p. 38), Gregory Dundas (2002, p. 434), é mais reticente em aceitar o relato de Dião Cássio. Para ele, o sentimento anti-egípcio no relato provém de Cássio e não de Augusto. Curiosamente, Dundas não cita Suetônio, o qual deve ter sido uma das referências de Dião Cássio, que escreveu em um período posterior. Para Dundas (2002), Augusto não teria se portado indevidamente em relação às práticas religiosas egípcias, pois se preocupava com a sua imagem, fato que explicaria a utilização de sua figura como faraó mantenedor de Maat na representação em cenas esculpidas em relevos de templos. Realmente, Augusto está representado nas paredes de templos, como é o caso, por exemplo, daquele de Kalabsha, localizado na Baixa Núbia (MartyndaleHoward, 2015, pp. 81-82). Também aparece em outros suportes, como em uma estela do Museu Carlsberg Glyptotek, em Copenhague, na qual faz oferendas a Buchis ${ }^{6}$, touro sagrado de Montu (Martyndale-Howard, 2015, p. 83). Essa outra documentação contraria a sua posição em relação ao touro Ápis nos relatos de Suetônio (Aug. 93) e Dião Cássio (Hist. Rom. LI.16.5).

Com explicar a aparente contradição? Concordo com Dundas (2002, pp. 433-436) no sentido de que Augusto deu atenção à forma como era representado no Egito, pois a ocupação da função de faraó exigia seguir a tradição, embora ele tenha inovado em relação ao seu nome no cartucho real, fator que gera dúvidas se ele era faraó de fato ou não. A meu ver, estamos diante de duas questões diferentes. Uma é a visão que Augusto tinha do Egito e, outra, é a sua política administrativa da província, que precisava considerar a tradição e as crenças locais. Nesse sentido, o relato de ambos os autores

\footnotetext{
${ }^{5}$ Faraó da XXVI Dinastia, Período Tardio, que teria reinado de 570-526 a.C.

${ }^{6}$ No Egito, além de Ápis, outros touros eram manifestações de divindades. Era o caso do touro Buchis, associado a Montu, deus de Hermonthis, na área tebana e de Mnevis, touro sagrado de Heliópolis, uma forma do deus-sol Rê (Shaw \& Nicholson, 1995, p. 56, p. 189).
} 
Mare Nostrum, ano 2020, v. 11, n. 2.

clássicos, Suetônio e Dião Cássio, podem ser analisados não do ponto de vista de uma verdade histórica, mas pelo contexto do grupo ao qual eles pertenciam, a um círculo intelectual no qual o Egito era visto de forma negativa e estereotipada, aspecto salientado pelo próprio Dundas (2002, p. 436). Portanto, a atitude imputada a Augusto, verídica ou não, mostra o desprezo da elite imperial romana para com o Egito, sobretudo após os acontecimentos de Ácio e a ameaça a Roma desempenhada por Cleópatra VII e Marco Antônio.

Uma outra questão que é motivo de debate entre os especialistas é a legitimação de Augusto como faraó, já que não houve cerimônia de coroação como acontecia com os Ptolomeus, que eram coroados em Mênfis pelos sacerdotes de Ptah. Também os imperadores romanos não usaram toda a titulatura que os faraós possuíam, que eram inscritas dentro dos cartuchos reais. A forma protocolar faraônica era composta por cinco títulos: nome de Hórus, nome das Duas Senhoras (as deusas protocolares do Alto e do Baixo Egito, Nekhbet e Uadjet), nome de Hórus de Ouro, nome de rei do Alto e do Baixo Egito ("Aquele do junco e da abelha") e nome de filho de Rê. Augusto reteve a fórmula do "nome de Hórus" e o "nome da coroação", que seria a translação do grego autocrator, “imperador” (Grenier, 1997, pp. 38-39).

Grenier (1997, p. 39) considera que, em primeiro lugar, estava a romanidade de Augusto, pois a tradução do seu nome de Hórus é a seguinte: “aquele que vela pela prosperidade do Egito, ele cuja potência é incomparável na cidade por excelência que ele ama, Roma”. Pela primeira vez, tem-se um faraó que não faz referência às divindades egípcias na fórmula protocolar e que era faraó porque tinha um império com sede em Roma. Isto explicaria o fato de Augusto querer ir à tumba de Alexandre, o Grande, sua referência, um rei conquistador do mundo, maior que os Ptolomeus, como ele próprio (Dundas, 2002, p. 441).

Contrariamente a Grenier, Martyndale-Howard (2015, p. 83) e Dundas (2002, p. 439) consideram que os egípcios viam Augusto como um faraó legítimo, apesar de ele não ter os cinco títulos e mesmo ao ter os seus cartuchos deixados em branco no templo de Kalabsha. Para Jodie Martyndale-Howard (2015, p. 82), a representação de Augusto como faraó nos templos egípcios é suficiente para considerá-lo enquanto tal. Para a

\footnotetext{
${ }^{7}$ A titulatura real incorporou elementos associados ao culto real que remontavam ao período Pré-dinástico e início do período dinástico (c. 2920 a.C.). A abelha aparece associada ao culto de Rê e ao Baixo Egito. As abelhas, segundo um mito egípcio, teriam sido formadas a partir das lágrimas do deus-sol que caíram na terra. Enquanto os governantes do Baixo Egito eram chamados "aqueles que pertencem à abelha", no Alto Egito eram “aqueles que pertencem ao junco" (Lurker, 1991, p. 32).
} 
mesma autora, os sacerdotes precisavam de Augusto para manter Maat, por isso a representação dele nas paredes dos templos não era simplesmente para manter a tradição, mas tinha um apelo real aos egípcios.

É difícil estabelecer uma conclusão a respeito desse assunto. Quando tratamos da produção das imagens há um certo consenso atualmente que Augusto ou aqueles que atuavam em seu nome, no caso o prefeito de Alexandria e do Egito, planejou a forma como o imperador seria representado oficialmente e mesmo a titulatura real, que deve ter sido feita junto aos responsáveis egípcios pela manutenção dos templos e sua organização. Com a nova estruturação dos templos feita por Augusto, os romanos passaram a controlar diretamente os sacerdotes, cuja nomeação dependia do aval da administração imperial. As terras dos templos, que eram fontes de recursos econômicos, foram confiscadas e tornaram-se terras imperiais, em 20 a.C. (Dundas, 2002, p. 447).

No entanto, quando tratamos da recepção das imagens, devemos pensar que não havia uma mesma resposta para todo o Egito. Martyndale-Howard (2015, p. 83) defende que Augusto era visto como faraó legítimo, pois os egípcios precisavam de um faraó para manter a ordem, Maat. Realmente, as imagens dos templos, esculpidas em relevo, mas também esculturas, pinturas e objetos rituais tinham uma função mágica para os egípcios. Mas a dúvida é se os egípcios realmente acreditavam que a ordem (Maat) estava mantida com os romanos.

Não podemos considerar os egípcios como uma categoria única e coesa. Os romanos foram habilidosos em dividir a população egípcia pelo censo entre os que tinham alguma ascendência grega ou macedônica (valorizados quanto ao pagamento de impostos e outras vantagens) dos egípcios nativos. Uma identidade egípcia mais arraigada existia sobretudo na região da Tebaida, no Alto Egito. Portanto, não é irrelevante o fato de a revolta contra os romanos ter acontecido exatamente nesse local, onde uma rebelião ocorrida no período ptolomaico se estendeu de 207/6 até 199/8 a.C. e chegou a estabelecer dois faraós tebanos, Haronnophris e Chaonnophris (Bowman, 1986, pp. 30-31).

O fato de acreditarem no poder mágico das imagens e na figura do faraó como mantenedor de Maat não significa que os egípcios não criticavam o poder estabelecido. Há vários exemplos do período faraônico de crítica social, sobretudo em períodos de distúrbios, invasões estrangeiras e fome. Textos como As Admoestações de Ipu-ur e as Profecias de Neferti $^{8}$ são exemplos disso. Da época ptolomaica e romana os textos de

\footnotetext{
${ }^{8}$ As Admoestações de Ipu-ur tratam das lamentações do sábio Ipu-Ur, o qual não hesita em criticar o faraó ou, segundo alguns, a própria divindade, pelas desgraças que ocorriam no país. A cópia é da XIX Dinastia,
} 
Mare Nostrum, ano 2020, v. 11, n. 2.

contestação aparecem no Alto e no Médio Egito e, provavelmente, eram originários dos templos de Khnum, em Esna e de Harsaphes, em Heracleópolis ${ }^{9}$. Esses textos estão em demótico ou grego (provavelmente uma tradução da língua egípcia) caso, por exemplo, da Crônica Demótica e do Oráculo do Oleiro. Alan Lloyd os chama de propaganda nacionalista ${ }^{10}$ contra os Ptolomeus, pois datam do período helenístico (1982, p. 33), embora uma literatura desse tipo devesse circular em períodos anteriores (1982, p. 41).

A Crônica Demótica $^{11}$ consiste em uma coleção de oráculos e predições, acompanhados por suas interpretações. Seriam provenientes do templo de Harsaphes, o deus-carneiro de Heracleópolis. Os textos são profecias preditas por um sábio ao rei Amirtaios ou ao último faraó nativo, Nectanebo $\mathrm{II}^{12}$. Em uma parte do texto é dito que "um homem de Heracleópolis governará depois dos estrangeiros" (Lloyd, 1982, p. 42), isto é, dos persas e dos macedônios. Para Lloyd (1982, p. 41), o texto data provavelmente da época de Ptolomeu III Evergeta II (246-221 a.C.) e se refere a uma família poderosa de Heracleópolis, cujos membros seriam descendentes da dinastia heracleopolitana que dominou o Egito durante o período saíta e núbio ${ }^{13}$. O restabelecimento de Maat aparece

Reino Novo (c. 1307-1196 a.C.) mas, pelo exame paleográfico, deve ser originária do Reino Médio (c. 2040-1640 a.C.; Araújo, 2000, pp. 175-176; Lichtheim, 2006, pp. 149-163). Já as Profecias de Neferti estão preservadas em um papiro da XVIII Dinastia (c. 1550-1307 a.C.), mas o texto pode ser considerado uma peça de propaganda do fundador da XII Dinastia, Amenemhat I (Reino Médio, c. 1991-1962 a.C.). No texto, Neferti, um sacerdote-leitor, prediz ao faraó Snefru (Reino Antigo, c. 2575-2551 a.C.) o caos social que seguirá ao seu reinado, com o país afundado em uma pobreza generalizada e a violência predominando em todo lugar. O fim das desgraças ocorrerá com a chegada de um faraó vindo do sul do Egito, que unificará novamente o país, no caso, Amenemhat I (Araújo, 2000, pp. 192-193; Lichtheim, 2006, pp. 139-145). Miriam Lichtheim (2006, p. 149), considera que esses eram escritos que tratavam de "desgraças nacionais", peças de retórica gerais, como a de Ipu-Ur ou de propaganda, caso das Profecias de Neferti. Portanto, não retratavam acontecimentos reais. Mas, acreditamos que os distúrbios ocorridos no Egito durante o Primeiro Período Intermediário (c. 2134-2040 a.C.) influenciaram, de certa forma, a confecção desses textos, os quais teriam, portanto, um respaldo histórico.

${ }_{9}$ Tanto Khnum quanto Harsaphes eram divindades representadas em forma de carneiro e eram deuses associados à criação. Khnum, o "de plumas altas e longos chifres" estava associado à catarata do Nilo em Elefantina, no Alto Egito, sendo sua função controlar a inundação do Nilo por meio das cavernas de Hapi, o deus que personificava a cheia. Em Esna, como deus criador, era representado como um oleiro que moldava os seres no seu entorno. Harsaphes ou Herishef era o deus da cidade de Hnes, localizada no Médio Egito, que os gregos denominaram Heracleópolis, por associação do deus com Héracles. O seu nome significa "aquele que está sobre o seu lago", provavelmente o lago sagrado do templo, em uma referência ao papel criador da divindade solar que emerge das águas primordiais de dentro de uma flor de lótus (Hart, 1986, pp. 85-87, pp. 110-112).

${ }^{10}$ Embora o termo seja moderno, Alan Lloyd (1982, p. 33) justifica a sua utilização por considerar que o mesmo se aplica por ocasiões em que um grupo social impõe ou encoraja determinada atitude por meio de mídia de comunicação.

${ }^{11}$ Papiro que se encontra na Biblioteca Nacional da França (BN E. G. 215).

${ }^{12}$ Ambos os faraós são do Período Tardio (c. 712-332 a.C.). Amirtaios (404-399 a.C.) foi faraó da XXVIII Dinastia e Nectanebo II (360-343 a.C.) da XXX Dinastia, a última egípcia antes do domínio persa.

${ }^{13}$ Os faraós núbios governaram o Egito durante a XXV Dinastia (c. $712-657$ a.C.). Já a Dinastia Saíta (a XXVI Dinastia, c. 664-525 a.C.) era de origem nativa. 
como algo essencial a ser feito pelo próximo faraó, já que a ordem divina tinha sido corrompida pela invasão estrangeira (Lloyd, 1982, p. 43).

O Oráculo do Oleiro sobreviveu apenas na versão em grego, em papiros que datam dos séculos II e III d.C. ${ }^{14}$, portanto, cópias da época romana. Na narrativa, a profecia, enviada por Hermes (deus egípcio Thot), é proferida por um oleiro, em transe, para o faraó Amenóphis. É predito que um rei mau será destinado ao país, o qual fundará uma nova cidade e um novo deus será introduzido. Provavelmente, é uma referência a Alexandre, Alexandria e a Serápis. Uma série de desgraças ocorre no país até que os gregos sejam derrotados e que o Agathodaimon ${ }^{15}$ abandone a cidade da costa (Alexandria) e vá para Mênfis, onde um novo rei será coroado. No texto, os estrangeiros são associados a Tífon, identificação grega para Seth (Lloyd, 1982, p. 51).

Embora Lloyd (1982, p. 55) acredite que a audiência do texto era circunscrita ao meio da elite e ao grupo de sacerdotes, é bem provável que a estória circulasse também oralmente. Em uma sociedade onde a maior parte da população era analfabeta, a oralidade exercia um papel primordial ${ }^{16}$. Além disso, a população local estava em contato direto com os sacerdotes por meio das festividades religiosas. $\mathrm{O}$ controle romano dos templos visava remeter para Roma o lucro que ele gerava em termos econômicos, mas também fiscalizar a ação dos sacerdotes, que poderiam incitar a população egípcia contra o domínio estrangeiro. Também contrário a essa ideia de restrição de circulação dos textos é Giovanni Bazzana (2018, p. 220). Para ele, o Oráculo do Oleiro teve grande circulação no início da dominação romana no Egito, sobretudo no meio privado, entre indivíduos que tinham um certo conhecimento de grego, ainda que rudimentar.

\section{A estela de Cornélio Galo}

Um documento em especial tem sido analisado pelos historiadores e arqueólogos e mostra a situação complexa do início do domínio romano no Egito. Trata-se de uma estela de granito, gravada em três línguas, hieróglifo, grego e latim, erigida a mando do prefeito do Egito e de Alexandria, Cornélio Galo, em 16 de abril de 29 a.C. Ela foi achada em

\footnotetext{
${ }^{14}$ Os papiros são os seguintes: P. Graf. (G. 29787), do séc. II d. C.; Papiro Rainer (G19813), do séc. III d.C. e o P. Oxy. (2332), do final do século III d.C. Todos estão escritos em grego, mas há uma informação no P. Rainer de que ele é uma tradução (Lloyd, 1982, p. 50). Giovanni Bazzana (2018, p. 211) cita mais um papiro que contém o texto. É o PSI 8.982, da Biblioteca Medicea Laurenziana, em Florença.

${ }^{15}$ O "bom gênio", divindade protetora da ordem dos daemones gregos. No Egito ptolomaico e romano era comum a sua representação em forma de serpente (Saglio, 1873, p. 131).

${ }^{16}$ Essa proximidade entre a oralidade e a escrita no Egito Antigo é analisada por Donald Redford (2008, p. 27-28).
} 
Mare Nostrum, ano 2020, v. 11, n. 2.

1896 em frente ao templo de Augusto na ilha de Philae, atual Assuã (Figura 1). Atualmente, a estela se encontra no Museu do Cairo.

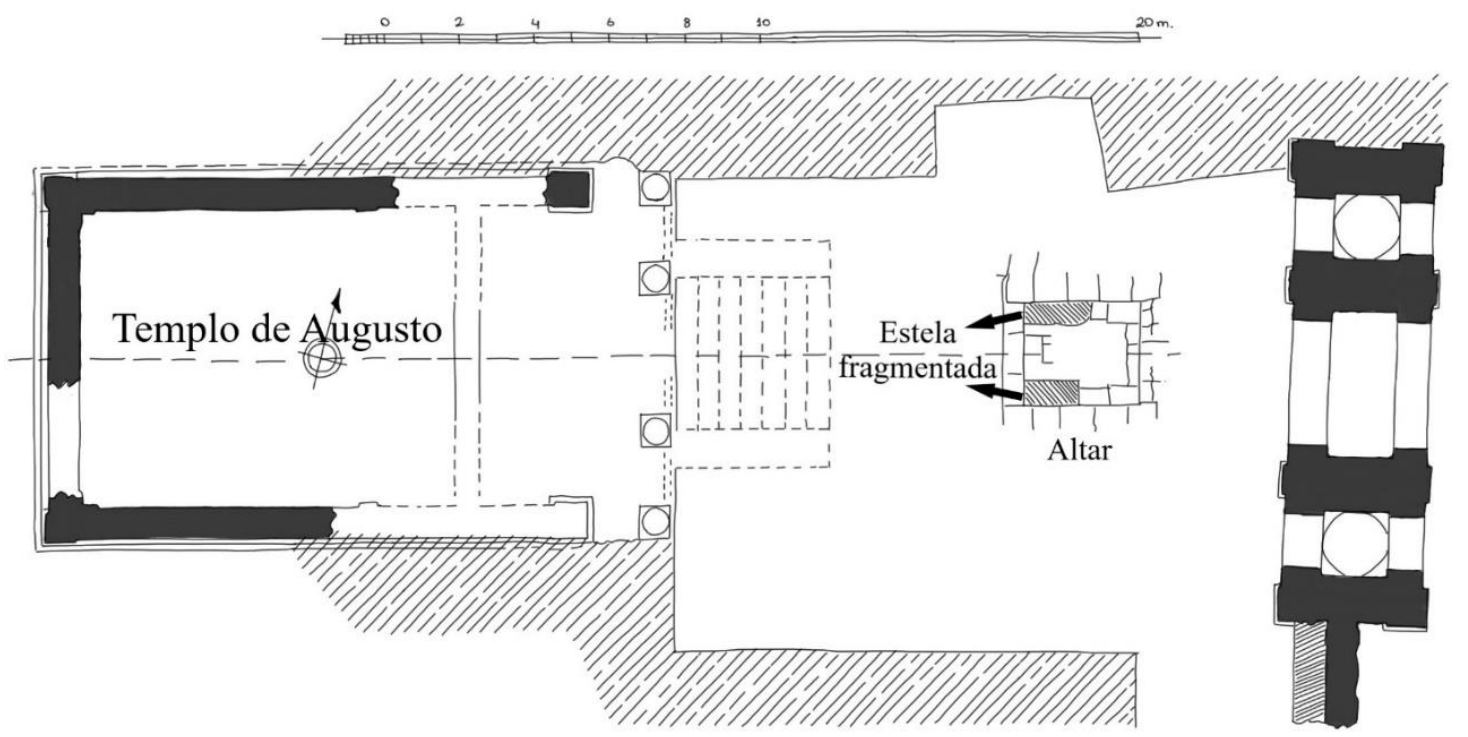

Figura 1. A estela de Cornélio Galo e sua localização

A estela foi encontrada fraturada em duas partes (hachuradas no desenho), que estavam dispostas abaixo do altar que ficava em frente ao templo de Augusto, localizado no santuário de Ísis na Ilha de Philae (Assuã).

Fonte: adaptado de Erman (apud Minas-Nerpel \& Pfeiffer, 2010, p. 268, Figura 6).

Após a conquista do Egito, o país se tornou uma província imperial administrada por um prefeito da ordem equestre. Augusto tinha receio de que o Egito fosse novamente palco de uma revolta ou fosse utilizado por algum senador que quisesse the arrebatar o poder, o que demonstra a importância estratégica do país para a política romana. Por isso, o Egito se tornou uma província sob a administração direta do imperador e não do senado. Os senadores e líderes da ordem equestre estavam proibidos de entrar no Egito sem anuência do imperador (Bowman, 1996, pp. 37-38). Em razão disso, o Egito ficou sendo administrado por uma espécie de governador (com título de prefeito), que pertencia à ordem equestre.

Mas mesmo o fato de o prefeito pertencer à ordem equestre não livrou Augusto de preocupações sobre as possibilidades de golpes contra o seu governo. Assim podemos 
perceber pelas análises que têm sido feitas a respeito da estela erigida por ordem de Cornélio Galo, o primeiro prefeito, para comemorar a vitória sobre os rebeldes do Alto Egito. Esta revolta na Tebaida ocorreu um ano após a conquista do Egito por Augusto, em 29 a.C. e está associada aos impostos cobrados pelos romanos da população. A revolta foi relatada por Estrabão (Geogr. XVII, 1.53), que esteve no Egito na época de Élio Galo, sucessor de Cornélio Galo, prefeito de Alexandria e do Egito, em 26 a.C.
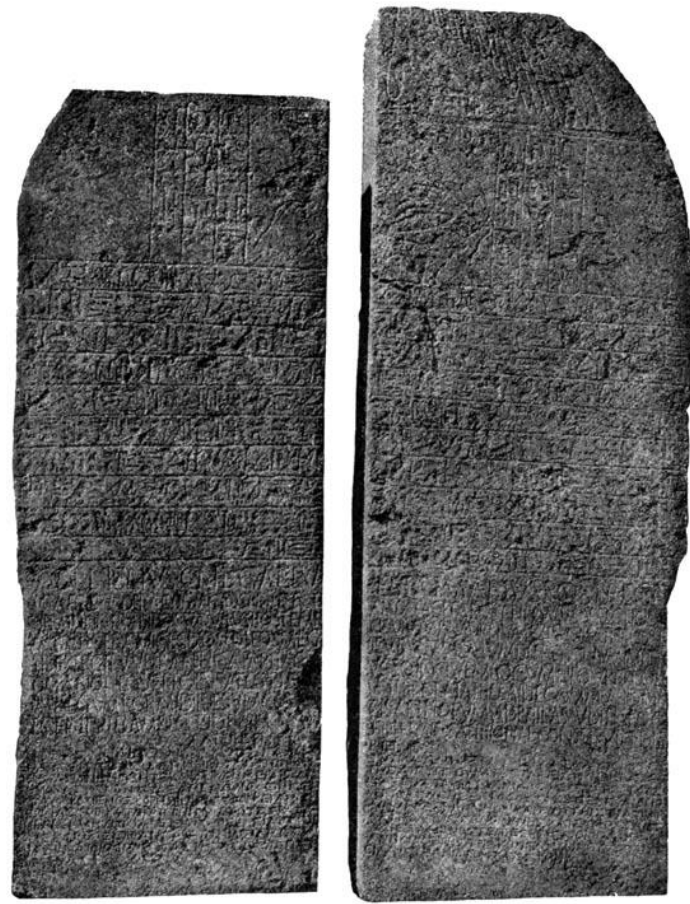

Figura 2. Estela de Cornélio Galo

Museu do Cairo, $\mathrm{n}^{\circ}$ de inventário: CG9295. Alt. 1,52m; L. 1,08m.

Proveniência: templo de Ísis na ilha de Philae (Assuã).

Disponível em: <https://commons.wikimedia.org/wiki/File:Stele_di_philae.jpg>. (Acesso em: 15 ago. 2020)

A estela possui um estilo de composição híbrido (Figura 2). Na sua forma, segue o padrão das estelas egípcias, possuindo um topo circular, com a representação do disco solar alado, uma forma de Hórus denominada Hórus de Behedet ${ }^{17}$ (detalhe da luneta da estela na Figura 3), cuja função apotropaica era proteger estelas e portais de templos egípcios. Abaixo está retratada uma figura a cavalo, em estilo helenístico, cuja interpretação é de difícil definição, já que a estela está danificada e há divergências entre

\footnotetext{
${ }^{17}$ No seu papel como Hórus de Behedet, uma cidade do Delta, o deus era representado como uma divindade celeste, sendo uma forma do disco solar com as asas do falcão (Shaw \& Nicholson, 1995, p. 134).
} 
Mare Nostrum, ano 2020, v. 11, n. 2.

os pesquisadores se o retratado é Augusto, na função de faraó, ou o próprio Cornélio Galo (Figura 3). Interpretações mais antigas, como a de Jean-Claude Grenier, considera ser o cavaleiro Augusto (Grenier, 1997, pp. 38-39). A interpretação mais recente de MinasNerpel e Pfeiffer (2010, p. 270) analisa como sendo o prefeito o cavaleiro. Entretanto, não seria o nome dele no cartucho e sim o de Augusto, chamado de Kaisaros (filho de César) na inscrição principal e de Romaios (o Romano), no topo da estela (Minas-Nerpel e Pfeiffer, 2010, p. 273).

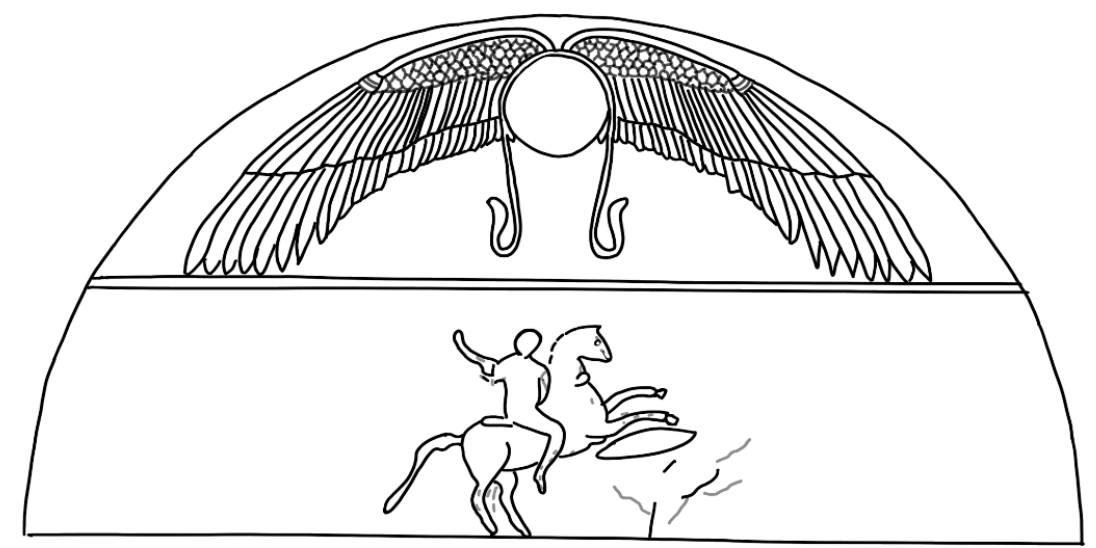

Figura 3. Reconstituição da luneta da estela de Cornélio Galo

Na luneta, Hórus de Behedet no topo.

Abaixo, Cornélio Galo a cavalo.

Fonte: adaptado de U. Denis (apud Minas-Nerpel \& Pfeiffer, 2010, p. 271, Figura 7).

A figura retratada em relevo escavado na rocha segura uma lança que brande sobre um inimigo caído no chão (Figura 3). O texto em hieróglifo faz referência aos deuses da primeira catarata do Nilo junto a Ísis e Osíris. A tríade divina da região de Elefantina é composta por Khnum, sua consorte Satis e a filha deles, Anukis. Esses deuses eram cultuados em Assuã, que formava a fronteira sul do Egito com a Núbia. Até então podemos considerar que houve uma adaptação romana da forma como o faraó era representado nos templos egípcios derrotando os seus inimigos, iconografia que já havia sido adaptada pelos Ptolomeus. No período faraônico o faraó aparece aprisionando os inimigos brandindo nas mãos uma maça de guerra ou uma lança. A partir do Reino Novo (c. 1550 a.C.) ele pode também ser representando sobre uma biga. Os inimigos do Egito derrotados eram povos estrangeiros, em geral, núbios, líbios ou asiáticos, que aparecem 
nos textos egípcios como os "nove arcos", que ameaçavam a ordem do país. Mas também poderiam ser os próprios egípcios que se rebelavam contra o sistema, contra a ordem, sendo, portanto, associados a isfet.

Com os Ptolomeus, o rei/faraó aparece em montaria, como no caso da estela de Raphia, também no Museu do Cairo, comemorando a vitória de Ptolomeu IV Filopátor sobre o rei selêucida Antíoco III, em 217 a.C. (Figura 4). Esse modelo iconográfico aparece no mosaico de Alexandre da Casa do Fauno, em Pompeia (Minas-Nerpel \& Pfeiffer, 2010, p. 275), mas já era corrente na imagética grega e macedônica. No Egito, a representação de deuses cavaleiros foi muito comum no período romano e se estendeu até o século IV d.C. Um exemplo é uma representação de Hórus a cavalo que fazia parte da moldura de uma janela de uma casa, tendo a função de espantar o mal (Museu do Louvre, E4850). Na cena em questão Hórus, como um cavaleiro romano, segura a lança contra Seth, em forma de crocodilo.

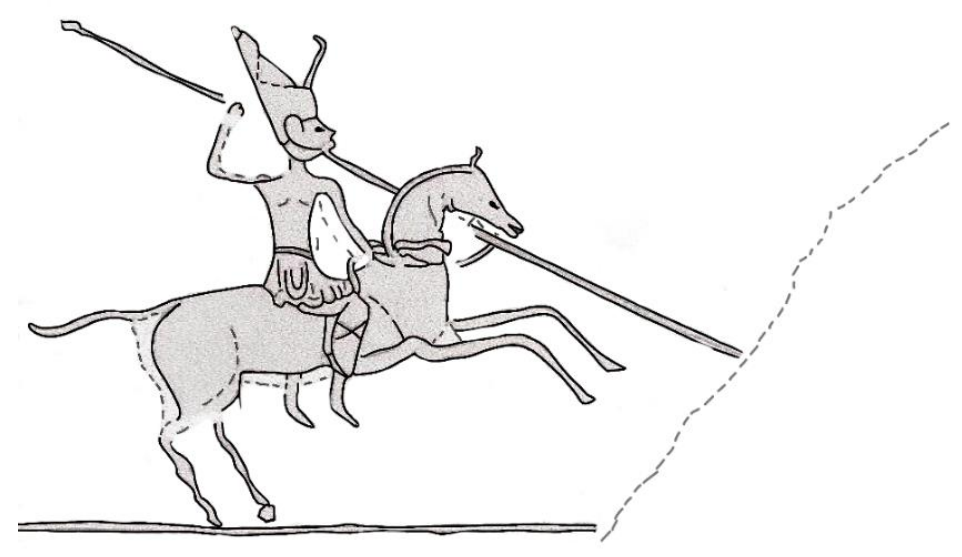

Figura 4. Reconstituição da estela de Raphia

Ptolomeu IV Filopátor como faraó porta o pschent (a coroa dupla do Alto e do Baixo Egito) e ataca os inimigos do Egito com uma lança.

Fonte: adaptado de U. Dennis (apud Minas-Nerpel \& Pfeiffer, 2010, p. 277, Figura 9).

Na estela de Cornélio Galo a função do faraó de manter a ordem sobre o caos é destacada no texto em hieróglifo que acompanha a imagem de Augusto/Galo: suas habilidades militares são salientadas, ele aparece recebendo tributos de terras estrangeiras como a Índia, Punt e a Núbia, constrói templos e santuários e doa presentes às divindades egípcias, sobretudo ao deus Khnum de Elefantina, sendo essa a razão da cheia abundante do Nilo (Minas-Nerpel \& Pfeiffer, 2010, p. 269). 
Mare Nostrum, ano 2020, v. 11, n. 2.

Normalmente, nas estelas do Egito ptolomaico as inscrições eram colocadas em três formas, a língua egípcia, em hieróglifo e demótico, e o grego. A estela de Cornélio Galo está escrita na língua egípcia (hieróglifo), em grego e em latim. No entanto, diferentemente do que acontecia com os Ptolomeus, o texto latino e grego (o grego sendo uma tradução do texto em latim) difere do texto em hieróglifo. No texto em hieróglifo César é o faraó que derrota os inimigos (fictícios) do Egito, situados em países longínquos como a Índia. No texto latino e grego os inimigos que ele derrota são os próprios egípcios, já que a estela faz referência à rebelião dos egípcios na Tebaida contra o domínio romano.

Existem casos em documentos egípcios nos quais os inimigos do Egito poderiam ser os próprios egípcios que se rebelaram contra o faraó, sendo associados às forças do caos e da desordem (Valbelle, 1990, p. 47). Exemplos do período ptolomaico são o Decreto de Mênfis (196 a.C.), que constitui o texto da Pedra de Rosetta, e o Segundo Decreto de Philae (186 a.C.). O contexto é o da "Grande Revolta" que se alastrou pelo Egito durante vários anos, após a morte de Ptolomeu IV Filopátor (221-205 a.C.). O Decreto de Mênfis glorificava as forças ptolomaicas pela destruição dos ímpios na cidade de Licópolis, onde estavam estabelecidos os rebeldes. Esses foram executados durante a cerimônia de coroação de Ptolomeu V Epifânio (205-180 a.C.), na data do Decreto de Mênfis, feito por ocasião da coroação ${ }^{18}$. O Segundo Decreto de Philae, dez anos após o Decreto de Mênfis, comemorava finalmente a vitória sobre o rebelde Chaonnophris, chamado de "inimigo dos deuses" (Veïsse, 2019, pp. 44-45).

A atitude dos sacerdotes egípcios para com os governantes estrangeiros do Egito não era unânime. Enquanto os Ptolomeus tiveram total apoio dos sacerdotes de Ptah, em Mênfis, o mesmo não aconteceu em outras localidades. Segundo Veïsse (2019, p. 45), os sacerdotes de Âmon, da cidade de Tebas, foram inicialmente favoráveis ao estabelecimento dos faraós locais, Haronnophris e, depois dele, Chaonnophris. Mas, depois da derrota da rebelião, voltaram a se alinhar com Alexandria.

Dois pontos importantes podemos pensar a respeito de nosso objeto de estudo, a estela de Galo, a partir dos apontamentos acima. Em primeiro lugar, o local. Philae está situada no Alto Egito, uma área tradicionalmente mais arraigada na tradição e identidade egípcias. Um segundo aspecto é que a estela de Cornélio Galo tem uma singularidade o texto em hieróglifo não é o mesmo da versão em grego e latim. A explicação mais lógica é que os sacerdotes de Ísis não quiseram colocar os egípcios como derrotados, tanto por

\footnotetext{
${ }^{18}$ Ptolomeu V foi coroado ainda criança, provavelmente em uma tentativa de restabelecer a paz no país, cuja administração estava a cargo de regentes.
} 
não terem sido favoráveis ao governo romano quanto por temerem a ação mágica da representação imagética e do texto em hieróglifo.

Como a estela foi encontrada nas escavações arqueológicas tombada com a face voltada para o chão, Jean-Claude Grenier (1997, p. 39) acredita que ela tenha sido propositalmente quebrada, para desfazer a sua ação mágica, já que os egípcios acreditavam no poder mágico tanto da escrita quanto da representação imagética. Grenier (1997, p. 39) acredita que os próprios sacerdotes do templo de Ísis em Philae teriam feito isso por ocasião da damnatio memoriae do prefeito Cornélio Galo, por volta de 27/26 a.C. Essa teoria de Grenier é contrariada pela hipótese de Mohamed Solieman (2014, p. 2) de que a estela foi quebrada para ser utilizada como material de construção para o templo de Augusto em Philae. Mas consideramos a questão ainda em aberto.

\section{A dupla Damnatio memoriae}

Teria Cornélio Galo sofrido uma dupla Damnatio memoriae? Uma egípcia, em relação à estela e, outra, nos relatos dos autores clássicos? Acreditamos que sim, no entanto, com objetivos diferenciados. Na estela, a tentativa de apagamento seria dos próprios governantes romanos, no caso Cornélio Galo, mas também Augusto, a quem ele representava. A outra danação seria entre os próprios romanos e está presente, sobretudo, no relato de Dião Cássio (Hist. Rom. LIII, 23.5-7).

A estela feita para Galo era um objeto oficial e mostra, provavelmente, uma das primeiras tentativas romanas de apropriação do cânone egípcio e macedônio da representação da realeza. Pensar no caráter mágico da estela e da imagem que ela contém é essencial para a compreensão da sua inutilização posterior à queda do prefeito. Toda forma de criação, seja ela uma pintura, escultura ou relevo poderia tomar vida por meio do ritual. Era dessa forma que os deuses poderiam se manifestar por meio de suas estátuas ou os mortos divinizados, cuja estátua $\mathrm{ka}^{19}$, depositada na capela funerária, era o elo de ligação entre os dois mundos, o divino e o terrestre. Na sociedade egípcia antiga, imagem e texto estavam intrinsicamente relacionados, sobretudo no caso dos hieróglifos, eles próprios constituídos por desenhos. Toda representação tinha o potencial de se tornar realidade, por meio da ação mágica do ritual.

\footnotetext{
${ }^{19} \mathrm{O} k a$ era a força vital de cada indivíduo, humano ou divino. Era por meio dele que era possível receber as oferendas de comida e bebida depositadas nos templos para os deuses ou na capela funerária para os mortos (Shaw \& Nicholson, 1995, p. 146).
} 
Mare Nostrum, ano 2020, v. 11, n. 2.

O cânone estabelecido para a imagética egípcia variou conforme o período, de modo que na própria estela elementos de origem helenística estão presentes. No entanto, a compreensão da sua função mágica permaneceu. Temos a representação de uma imagem ideal - do rei (ou governante) a cavalo, que destrói os inimigos do Egito, que remete a um padrão do faraó afastando isfet e mantendo Maat, que estava presente desde o período Pré-dinástico. O foco da imagem egípcia estava na reprodução da ideia, de um conceito, a fim de captar a essência de um objeto (Angenot, 2015, p. 105). A cena em questão não era apenas de um governante em batalha, mas ela tinha poder de ação, a agência lhe sendo dada pelo seu caráter mágico. A função apotropaica também é realçada pelo Hórus de Behedet (o disco solar com as asas do falcão e as duas serpentes $\operatorname{uraei}^{20}$ ) esculpido no topo da estela, a forma protocolar de proteção para monumentos egípcios.

Também a sua materialidade e localização no templo merecem atenção. A estela foi confeccionada de granito vermelho de Assuã, um material nobre reservado para construções estatais. Os egípcios davam especial atenção para certos tipos de rocha, que tinham um papel simbólico importante, tanto pela sua durabilidade e resistência quanto pela sua coloração. Os monumentos eram construídos para durar, com o objetivo de preservar a memória, seja do governante ou de um indivíduo particular. Enquanto a vida humana é curta, os materiais de rocha tinham a possibilidade da eternização, sendo incorruptíveis (Wilkinson, 1994, pp. 88-89). A cor avermelhada pode indicar uma associação com divindades solares, como o próprio Hórus, presente na estela.

Sonia Hazard chama a atenção para a necessidade de se considerar o papel da materialidade nos contextos religiosos, já que a religião está presente nas "mídias", nos suportes e nos espaços de culto e rituais (Hazard, 2013, pp. 67-68). Para Lynn Meskell (2005, p. 5), as coisas materiais serviam, na cultura egípcia, como meio de comunicação entre o plano divino, o humano e o mundo dos mortos, não havendo dicotomia entre sujeito e objeto. No caso específico da estela de Cornélio Galo, a materialidade também indica o poder daquele que é capaz de edificar e erigir monumentos, prerrogativa do faraó. Por isso, se o retratado na figura a cavalo for mesmo Cornélio Galo, ele cometeu uma infração contra Augusto, colocando-se no seu lugar.

Apenas quando consideramos a importância da materialidade, é que podemos perceber o significado, para os egípcios, de a estela ter sido inutilizada e, provavelmente,

\footnotetext{
${ }^{20}$ A palavra de origem grega uraeus provavelmente, é uma corruptela da expressão egípcia "aquela que se ergue", em uma referência à cobra naja, que era identificada ao olho de Rê. Quando representada nas coroas tinha a função de proteger o rei (Lurker, 1991, p. 125).
} 
tombada. Para Sylvie Calville e Mohammed Ali (2013, p. 284), os sacerdotes egípcios danificaram a estela partindo-a em duas partes e depositando-a, voltada para baixo, no pavimento do templo de Ísis. Realmente, o corte da estela foi feito propositalmente e segue o padrão dos cortes simétricos que os egípcios faziam em seus monumentos. Ela pode ter sido utilizada, posteriormente, como material de construção para o templo de Augusto, datado de 13-12 a.C. por meio de uma dedicatória ao imperador e a Roma feita pelo então prefeito, Rúbrio Bárbaro (Calville \& Ali, 2013, p. 283). No entanto, é provável que a inutilização da estela tenha ocorrido logo após o afastamento de Galo e o seu consequente suicídio.

O tombamento de estátuas e monumentos era algo comum no Egito por ocasião da Damnatio memoriae. Imagens de criminosos eram destruídas, assim como aquelas de faraós que não mantiveram Maat, como foi o caso, por exemplo, de Akhenaton ${ }^{21}$ (Meskell, 2004, p. 8). Augusto mesmo teve as suas estátuas derrubadas no Egito pelos núbios comandados pela rainha Amanirenas, que tinha o título de Candace, em 24 a.C. (Estrabão, Geogr. XVII, 1.54). A cabeça de uma delas foi decepada e colocada no solo diante de um templo (Calville \& Ali, 2013, p. 284).

Como a estela está danificada, não sabemos quem está representado sendo pisoteado pelo cavalo conduzido por Galo/Augusto. No texto escrito em hieróglifo há referência aos deuses da primeira catarata do Nilo, a tríade familiar composta por Khnum, Satis e Anukis. O rei (Galo/Augusto) aparece como responsável por destruir os inimigos do Egito, apontados como estrangeiros de países longínquos, e de propiciar a cheia do Nilo, uma amostra da manutenção de Maat. Contrariamente ao que acontecia na época ptolomaica, os sacerdotes de Philae não quiseram colocar os rebeldes egípcios como os derrotados. Não sabemos se os romanos concordaram com esse aspecto da estela ou mesmo se sabiam o que estava escrito, já que o conhecimento de hieróglifo era reduzido no Egito. No entanto, na administração ptolomaica e, posteriormente, também na romana, existiam os tradutores intérpretes, sobretudo para casos de documentos oficiais.

Ao que parece, a estela estava direcionada a grupos distintos, sendo que a parte em hieróglifo era destinada aos egípcios e as outras duas, em grego e latim, aos falantes de grego e aos romanos. Mas, após trezentos anos de dominação lágida, o grego não era uma língua tão estranha aos egípcios. Provavelmente, os egípcios que conheciam uma leitura, ainda que rudimentar, de grego, poderiam passar adiante a informação aos outros. Além

\footnotetext{
${ }^{21}$ Faraó da XVIII Dinastia, Reino Novo (c. 1353-1335 a.C.).
} 
Mare Nostrum, ano 2020, v. 11, n. 2.

disso, existiam famílias que transitavam nas duas esferas culturais, grega e egípcia, sendo fruto de casamentos mistos. Havia também a possibilidade de transmissão oral, aspecto importante que muitas vezes os especialistas não levam em consideração, pois acreditam apenas na sua função para sociedades iletradas. Mas no Egito a palavra fazia parte do ritual, assim como a memorização, e o templo não estava isolado do meio social ao qual estava inserido.

No texto latino os inimigos estão claros, pois há referência às cidades do Alto Egito sublevadas e derrotadas pelo prefeito. Mohamed Solieman (2014, pp. 2-3) apresenta um trecho da inscrição latina e sua tradução para o inglês ${ }^{22}$, embora na reprodução do texto original ele tenha suprimido uma parte:

Gaio Cornélio Galo, filho de Gnaio, cavaleiro romano, primeiro prefeito de Alexandria e do Egito, após a derrota dos reis por César, filho do divino, e vencedor da revolta da Tebaida em quinze dias - derrotou o inimigo duas vezes na batalha geral e tomou cinco cidades pela força: Boreses, Coptos, Ceramici, Diópolis Magna e Ophion, e tendo capturado os líderes dessa revolta, tendo levado o seu exército além da catarata do Nilo, onde nem os exércitos dos romanos nem aqueles dos reis do Egito tinham ido antes, e subjugado a Tebaida, fonte de pavor de todos os reis, e tendo dado audiência aos embaixadores do rei da Etiópia, e tendo tomado aquele rei sob sua proteção e apontado um tyrannus (governante) para o Tiracontoschoenus [...] na (?) Etiópia, ele (i. e. Galo) fez esta dedicatória e deu graças aos deuses ancestrais e ao Nilo, seu ajudante ${ }^{23}$ (Soleiman, 2014, pp. 2$3)$.

\footnotetext{
22 "Gaius Cornelius Gallus son of Gnaius, the Roman cavalryman, first prefect of Alexandria and Egypt after the defeat of kings by Caesar sono $f$ the divine, and the vanquisher of Thebaid's revolution in fifteen days, defeated the enemies twice during it in a general battle, and took over five cities by force: Boreses, Coptos, Ceramici, Diospolis Megaly, and Ophion, and having captured the leaders of these revolutions, having led his army beyond the cataract of the Nile, where neither the armies of the Romans nor those of the kings of Egypt had gone before, and subjugated Thebaid, the source of dread for all kings, and given listening to the ambassadors of the king of Aethiopia and taken that king into protection, and appointed a tyrannus (ruler) for the Tiracontoschoenus [...] in (?) Aethiopia, he (sc. Gallus) presented this dedication and gave thanks to the ancestral gods and the Nile, his helper" (Solieman, 2014, pp. 2-3).

${ }^{23}$ C. Cornelius Cn.f. Gaius eques Romanus post reges a Caesare deivif. devictos praefectus Alexandreae et Aegypti primus, defectionis Thebaidis intra dies XV quibus hostem vicit, bis acie victor, $V$ urbium expurgnator Boreseos Copti Ceramices Diospoleos megales Ophieu, ducibus earum defectionum interceptis, exercitu ultra Nili catarhacten transdueto, in quem locum neque populo Romano neque regibus Aegypti arma ante sunt prolata, Thebaide, communi omnium regum formidine, subaeta legatisqe Regis Aethiopum ad Philas auditis coque piae constituto, dieis patrieis et Nilo adiutori (Solieman, 2014, p. 2).
} 
Além de os egípcios aparecerem como inimigos e a Tebaida ser descrita como "fonte de pavor de todos os reis" (Solieman, 2014, p. 3), Cornélio Galo aparece como dando audiência aos embaixadores etíopes e nomeando um governante para a região da Baixa Núbia, então denominada de Triacontaschoenus (a Dodecaschoenus dos Ptolomeus). Galo, embora faça referência a César como faraó, toma para si as prerrogativas de rei, recebendo dignatários estrangeiros (etíopes) e colocando o rei etíope sob a sua proteção. Segundo Solieman (2014, p. 4), Galo conseguiu converter a Baixa Núbia em um reino cliente de Roma. Há dúvidas em relação a essa interpretação, apontada pelo próprio Solieman (2014, p. 4) de que poderia ser uma relação de amizade mais do que o estabelecimento de uma clientela. Nesse caso, haveria um exagero por parte de Galo, assim como na parte em que ele diz que nenhum exército tinha anteriormente ido além da Primeira Catarata.

Os etíopes, relatados na estela, eram os núbios de Méroe, que os romanos tiveram dificuldade de controlar. $\mathrm{O}$ acordo núbio com os romanos feito por Cornélio Galo foi rompido com o prefeito seguinte, Élio Galo (27 a.C.). Quando esse estava em campanha militar na Arábia, os núbios aproveitaram os poucos soldados presentes no Egito para invadir a Tebaida (Milne, 1924, pp. 6-10). Tais conflitos se estenderam posteriormente, já no governo de Petrônio, prefeito de 25 a 21 a.C., com os núbios sendo liderados pela rainha Candace (Estrabão, Geogr. XVII, 1.54), a que já referimos anteriormente. O conflito entre Roma e Méroe só teve fim com a paz selada em Samos, em 21-20 a.C., com o estabelecimento da fronteira sul do Império Romano em Hierasycaminos (Maharraqa).

A Tebaida era uma região importante para a administração do Egito, pois dela partiam as rotas comerciais para o Deserto Oriental e os portos do Mar Vermelho, que faziam a conexão com a Arábia e a Índia. Além disso, era o canal de comunicação egípcio com o interior da África (Herklotz, 2012, p. 17). Por isso, Augusto construiu vários templos na Baixa Núbia, onde ele aparece adorando divindades egípcias e núbias (MinasNerpel \& Pfeiffer, 2010, p. 274). Portanto, acordos diplomáticos com os núbios eram essenciais para se manter a fronteira sul do Egito e para a consolidação da presença romana no Egito.

Se Cornélio Galo se portou ou não como faraó é um dilema difícil de solucionar. Ele parece ter tomado atitudes exageradas, que o prejudicaram junto a Augusto. $\mathrm{O}$ discurso político era algo comum no Egito e entre os romanos e tinha implicações em relação à disputa de poder. Provavelmente, Augusto, pela recente guerra contra Marco Antônio e Cleópatra VII, não confiava em seus subordinados, mesmo Cornélio Galo 
Mare Nostrum, ano 2020, v. 11, n. 2.

sendo seu homem de confiança, tendo estado ao seu lado na guerra contra os Ptolomeus e Antônio. De qualquer forma, o prefeito caiu em desgraça e a sua queda resultou no seu suicídio.

A Damnatio memoriae romana de Cornélio Galo tem sido atribuída à inveja do círculo aristocrático romano ao qual ele pertencia (Calville \& Ali, 2013, p. 284). Como resultado do complô, Galo foi proibido de morar nas províncias do imperador, perdeu cargos, prestígio, foi exilado e privado de seu patrimônio (Dio Cass., Hist. Rom. LIII.23.57). Qual o motivo alegado? Suetônio fala da natureza invejosa do prefeito (Aug. 66). Dião Cássio (Hist. Rom. LIII.23.5-6) acrescenta um aspecto interessante, ao colocar entre as ações repreensíveis do prefeito o fato de ele ter mandado erguer estátuas suas por todo o Egito e inscrever nas pirâmides os seus feitos. Embora haja exageros na retórica de Cássio, a estela não deixa de ser um exemplo desses monumentos.

O episódio narrado por Dião Cássio guarda os resquícios da razão da queda de Cornélio Galo, por ameaçar a posição de Augusto. No entanto, também realça o complô armado contra ele, que envolvia traições e interesses políticos daqueles que anteriormente eram seus amigos, como Valério Largo, seu denunciante (Dio Cass., Hist. Rom. LIII.23.6). Se era a intenção de Cornélio Galo se indispor com Augusto, não sabemos de fato, mas é improvável. No entanto, na estela houve uma sobreposição de papeis entre Cornélio Galo e Augusto. A estela nos dá a entender que, de certa forma, ambos se confundem e estão numa posição designada ao faraó do Egito. Cornélio Galo estaria ciente das implicações de suas atitudes?

Os egípcios estavam habituados ao tipo de representação presente na estela, pois, ainda que modificada por elementos próprios da cultura grega e macedônia, remetia a uma tradição faraônica. Resta saber se a mensagem de pacificação foi bem recebida, pelo uso da ideologia real de manutenção de Maat. Na nossa opinião, não. Assim como também não foi por Augusto, já que Cornélio Galo foi acusado de ter tomado atitudes de consagração que foram vistas como ameaçadoras e que extrapolavam a sua função de prefeito.

\section{Conclusão}

Elencamos como objeto de estudo principal a estela de Cornélio Galo, primeiro prefeito de Alexandria e do Egito, no início da administração romana do Egito (30-29 a.C.), ainda antes de Otávio receber o título de Augusto. A estela, originalmente erigida 
no templo de Ísis, na ilha de Philae (Assuã), encontra-se no Museu do Cairo (CG9295). Por não estar bem preservada apresenta muitos pontos de discussão. A fim de demonstrar que os egípcios não aceitaram facilmente o domínio romano, a partir do objeto selecionado, abordamos três aspectos que consideramos importantes discutir: a ideologia real no Egito Romano, a estela enquanto objeto material e as implicações da Damnatio memoriae do prefeito para egípcios e romanos.

A ideologia real no Egito Antigo aparece estabelecida desde o período Pré-dinástico e era fator de coesão social e política na figura do faraó, o responsável por manter a ordem cósmica, na forma de Maat, uma divindade que incorporava os conceitos de justiça, verdade, equilíbrio. Por isso, os governantes estrangeiros do Egito assumiam a titulação de faraó e assim eram representados na iconografia oficial, na estatuária e nos relevos das paredes dos templos.

Os imperadores romanos, ao contrário dos Ptolomeus, não possuíam a titulação completa de faraós, fator que gera dúvidas quanto a sua legitimação de fato frente aos egípcios. No entanto, mesmo a crença na ação mágica dessas imagens, inerente à visão de mundo egípcia, não impedia a contestação política de governantes, caso esses não seguissem Maat e fossem responsáveis pela desordem e agitação social. Para o período romano conhecemos alguns textos, em formato de profecias, que previam a volta de um faraó nativo para restabelecer Maat no Egito. Embora datem de uma época anterior, do período ptolomaico ou persa, o Oráculo do Oleiro e a Crônica Demótica demonstram uma oposição aos estrangeiros, capitaneada por sacerdotes oriundos de templos do Médio (Heracleópolis Magna) e do Alto Egito (Esna).

A estela de Cornélio Galo pode ser pensada como elemento da Damnatio memorae do prefeito tanto para egípcios quanto para os romanos, embora as intenções fossem diferentes. A estela era negativa para os egípcios, ao retratá-los como derrotados pelo poder romano, estabelecido na forma da realeza adotada por Galo enquanto representante de Augusto. A ideologia real faraônica foi utilizada, na parte escrita em hieróglifos, para mostrar Galo na função de faraó, que é responsável por manter Maat, agradar aos deuses e dar prosperidade ao Egito, como a cheia do Nilo. E, na parte escrita em latim, com tradução também em grego, Galo se vangloria da derrota egípcia, em um texto provavelmente direcionado aos falantes de grego e aos romanos. Normalmente, nos decretos trilíngues da época ptolomaica um texto era tradução do outro, fato que demonstra a singularidade da estela de Galo e leva à ideia de que os sacerdotes do templo 
Mare Nostrum, ano 2020, v. 11, n. 2.

de Ísis, em Philae, onde a estela foi encontrada, elaboraram um outro texto em hieróglifo, que não se contrapunha aos egípcios.

Após a Damnatio memoriae do prefeito, por volta de 27-26 a.C., a estela foi cortada ao meio propositalmente e, mais tarde (13-12 a.C.), utilizada como material de construção para o templo de Augusto, no próprio santuário de Ísis, em Philae. Como os egípcios acreditavam no poder mágico dos objetos, provavelmente a destruição da estela foi providenciada quando Galo não era mais o favorecido de Augusto. Dessa forma, a ação romana contra os egípcios ficava neutralizada magicamente. A estela também pode ser útil para analisarmos a postura romana em relação a Cornélio Galo e sua Damnatio memoriae. As fontes clássicas tratam de sua inveja para com Augusto e de suas atitudes que exacerbaram a sua função de prefeito (Suet. Aug. 66; Dio Cass., Hist. Rom. LIII.23.57). Não acreditamos que a estela em si tenha sido causa da celeuma entre os romanos. Mas, tendo ou não Galo a intenção de se sobrepujar a Augusto, o fato é que a estela é exemplo da sua colocação na função de faraó, mostrando os seus grandes feitos, tanto para com egípcios quanto para com os núbios de Méroe, elemento que pode ser interpretado como uma ameaça ao imperium de Augusto.

Recebido: $30 / 08 / 2020$

Aprovado: $29 / 10 / 2020$ 


\section{REFERÊNCIAS BIBLIOGRÁFICAS}

Fontes

Dio Cassius (1917). Roman History (Books LI-LV). London: Harvard University Press (Loeb Classical Library, vol. VI).

Heródote. (1967). Histoires (Livre III. Thalie). Paris: Les Belles Lettres.

Srabon. (2015). Géographie (Livre XVII 1ª partie. L’Égypte et l'Éthiopie nilotique). Paris, Les Belles Lettres.

Suétone. (2013). Vies des douze Césars (César-Auguste). Paris: Les Belles Lettres.

Obras

Angenot, V. (2015). Semiotics and Hermeneutics. In M. K. Hartwig (Ed.). A Companion to Ancient Egyptian Art (pp. 98-119). Chichester: Wiley Blackwell.

Araújo, E. (2000). Escrito para a eternidade: a literatura no Egito faraônico (pp. 173200). Brasília: Ed. UnB.

Assmann, J. (2010). Maât. L'Égypte pharaonique et l'idée de justice sociale. Paris: MdV.

Baines, J. \& Málek, J. (1996). O Mundo Egípcio. Deuses, templos e faraós (vol. 1, pp. 36-37). (Grandes Impérios e Civilizações). Madrid: Edições Del Prado.

Bazzana, Giovanni B. (2018). The Oracle of the Potter and the "Apocalyptic Worldview" in Egypt. Ephemerides Theologicae Lovanienses, 94(2), 207-222.

Bowman, A. (1986). Egypt after the Pharaohs - 332 BC-AD642 from Alexander to the Arab Conquest. London: British Museum Press.

Cauville, S. \& Ali, M. I. (2013). Philae. Itinéraire du visiteur. Leuven: Peeters.

Dundas, G. S. (2002). Augustus and the Kingship of Egypt. Historia: Zeitschrift für Alte Geschichte, 51 (4), 433-448.

Grenier, J. C. (1997). L'empereur et le pharaon. In L'Égypte Romaine: l'autre Égypte (pp. 38-40). Marseille, Musée d'Archéologie méditerranée: Réunion des musées nationaux.

Hart, G. (1986). Heryshaf; Khnum. In G. Hart (Ed.). A Dictionary of Egyptian Gods and Goddesses (pp. 85-87; pp. 110-112); London: Routledge.

Hazard, Sonia (2013). The Material Turn in the Study of Religion. Religion and Society: advances in Research 4, 58-78. 
Herklotz, F. (2012). Aegypto Capta. Augustus and the Annexation of Egypt. In C. Riggs (Ed.), The Oxford Handbook of Roman Egypt (pp. 11-21). Oxford: Oxford University Press.

Kemp, B. J. (2018). Ancient Egypt: Anatomy of a Civilization. London; New York: Routledge.

Lichtheim, M. (2006). Ancient Egyptian Literature: The Old and Middle Kingdoms (Vol. I, pp. 139-145, pp. 149-163). Berkeley; Los Angeles; London: University of California Press.

Lloyd, A. B. (1982). Nationalist Propaganda in Ptolemaic Egypt. Historia: Zeitschrift für Alte Geschichte, 31(1), 33-55.

Lurker, M. (1991). Bee; Uraeus. In M. Lurker (Ed.). The gods and symbols of Ancient Egypt: ann illustrated dictionary (p. 32; p. 125). London: Thames and Hudson.

Martyndale-Howard, J. (2015). Augustus: Caesar and god. Varying Images of the first Roman Emperor. In C. Klose, L. C. Bossert \& W. Leveritt (Ed), Fresh Perspectives on Graeco-Roman Visual Culture (pp. 77-86). Proceedings of an International Conference at Humboldt-Universität, Berlin, 2nd-3rd September 2013.

Meskell, L. (2005). Introduction: Object Orientations. In L. Meskell (Ed.). Archaeologies of Materiality (pp. 1-17). Malden: Blackwell.

Meskell, L. (2004). Object Worlds in Ancient Egypt. Material Biographies Past and Present. Oxford; New York: Berg.

Milne, J. G. (1992). A History of Egypt under Roman Rule. Chicago: Ares Publishers.

Minas-Nerpel, M. \& Pfeiffer, S. (2010). Establishing roman rule in Egypt: the trilingual stela of C. Cornelius Gallus from Philae. In K. Lembke, M. Minas-Nerpel \& S. Pfeiffer (Org.), Tradition and transformation: Egypt under Roman Rule (pp. 265298). Leiden; Boston: Proceedings of the International Conference, Hildesheim, Roemer-and Pelizaeus-Museum, 3-6 July 2008.

Orlin, E. M. (2008). Octavian and Egyptian Cults: redrawing the boundaries of Romanness. American Journal of Philology, 129 (2), 231-253.

Redford, D. B. (2008). History and Egyptology. In R. H. Wilkinson (Ed.), Egyptology Today (pp. 23-35). Cambridge: Cambridge University Press.

Saglio, E. (1873). Agathodaemon. In M. C. Daremberg \& E. Saglio (Eds.), Dictionnaire des Antiquités grecques et romaines (p. 131). Recuperado de http://dagr.univtlse2.fr/.

Shaw, I. \& Nicholson, P. (1995). Buchis; Horus; Ka; Montu. In I. Shaw \& P. Nicholson (Eds), The Dictionary of Ancient Egypt (p. 56; pp. 133-134; p. 146; p. 189). London: British Museum Press. 
Solieman, M. G. (2014). Cornelius Gallus, Praefectus Aegypti, and Aethiopia: a self propagandist, Journal of Ancient History, 17, 1-27.

Valbelle, D. (1990). Les Neuf Arcs. L'égyptien et les étrangers de la préhistoire à la conquête d'Alexandre. Paris: Armand Colin.

Veïsse, A. E. (2019). The Last Pharaohs: the Ptolemaic Dynasty and the Hellenistic World. In K. Vandorpe (Ed.), A Companion to Greco-Roman and Late Antique Egypt (pp. 35-49). Medord: Blackwell.

Wilkinson, R. H. (1994). Symbol \& Magic in Egyptian Art (p. 137; pp. 88-89). London: Thames and Hudson.

Zanker, P. (1990). The Power of Images in the Age of Augustus. Ann Arbor: The University of Michigan Press. 
Mare Nostrum, ano 2020, v. 11, n. 2.

\section{Propaganda ANd Resistance in Roman EgyPt: \\ The Stele of Cornelius Gallus}

\section{ABSTRACT}

Roman Egypt was a multiple and heterogeneous society that can be analyzed not only from the perspective of continuity elements with tradition from the pharaonic period but also with transformations resulting from the series of foreign conquests that were inflicted to the country. With royal ideology in Roman Egypt in mind, we aim to approach it taking into account two distinct views: Its value as an element of political propaganda used by its Roman governors and its use as a form of Egyptian resistance to foreign domination. A special element for our interpretation is the stele of Cornelius Gallus, first prefect of Alexandria and Egypt.

\section{KEYWORDS}

Roman Egypt; royal ideology; propaganda; resistance; Cornelius Gallus. 